\title{
Isoindoloindolones - biological activities and syntheses
}

\author{
Hari K. Kadam ${ }^{a, b}$ and Santosh G. Tilve ${ }^{* a}$ \\ ${ }^{a}$ Department of Chemistry, Goa University, Taleigao Plateau, Goa - 403 206, India \\ ${ }^{b}$ Present address: Department of Chemistry, St. Xavier's College, Goa - 403 507, India \\ E-mail: stilve@unigoa.ac.in
}

DOI: $\underline{\text { http://dx.doi.org/10.3998/ark.5550190.p009.316 }}$

\begin{abstract}
This review describes the biological activity and synthesis of structurally and biologically significant isoindoloindolone compounds. The various synthetic reports are mainly described under two headings based on use of palladium chemistry or the Wittig reaction as the key step for the construction of the indole or isoindole ring. Other methods are included in the miscellaneous approaches.
\end{abstract}

Keywords: Isoindoloindolones, bioactivity, synthesis, Wittig reaction, cyclisation

\section{Table of Contents}

1. Introduction

2. Biological Activity

3. Synthetic Strategies

3.1 Palladium catalyzed coupling reactions

3.2 Wittig reactions

3.3 Miscellaneous approaches

4. Conclusions

\section{Introduction}

Indole based compounds are frequently encountered in bioactive substrates. $6 H$-Isoindolo[2,1- $a$ ]indol-6-one $\mathbf{1}$ is a predominant candidate of such type. Structurally it is a tetracyclic system having an indole ring fused to an isoindoline moiety with tethered (bridgehead) nitrogen (Figure 1). 


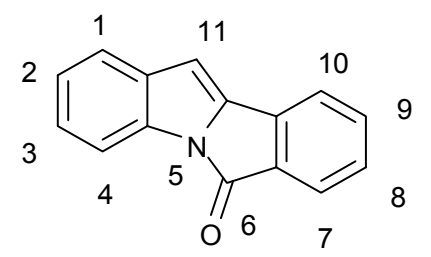

1

Figure 1. $6 H$-Isoindolo[2,1-a]indol-6-one.

Although this heterocyclic structural motif is yet to be revealed in any natural product, it has already received a position of major importance as a bioactive compound. ${ }^{1-4}$

\section{Biological Activity}

The derivatives of isoindoloindolone are well known for their specific bioactivity profiles. Isoindoloindolone derivatives are reported as potent ligands of $\mathrm{MT}_{3}{ }^{5}$ The third melatonin binding site, $\mathrm{MT}_{3}$, is an enzyme, quinone reductase- 2 and not a usual seven transmembrane domains receptor. Hydroxyisoindoloindolone derivative $\mathbf{2 a}$ has subnanomolar affinity for the melatonin binding site $\mathrm{MT}_{3}$.<smiles>COc1cc2c(cc1OC)C1N(C2=O)C(=O)c2cc3cc(O)ccc3n21</smiles>

2a<smiles>CCN(CC)CCNc1ccc(Cl)c2c1C(=O)n1c-2cc2ccccc21</smiles>

$2 b$<smiles>CCNCCC(=O)Nc1ccc2c3ccccc(C)c-3cc2c1</smiles>

2c

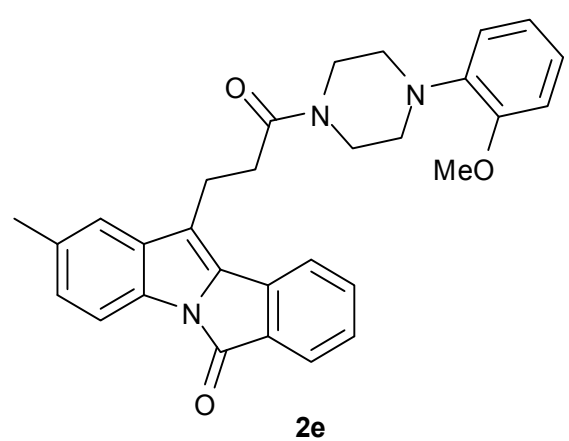

Figure 2. Biologically important isoindoloindolones.

Chloroisoindoloindolone derivative $\mathbf{2 b}$, amidoisoindoloindolone derivative $\mathbf{2 c}$, and aminoisoindoloindolone 2d show DNA binding ability and non-specific interference with the topoisomerase-I catalytic cycle (Figure 2). Compound $\mathbf{2 b}$ also has an antiproliferative effect 
against HT-29 and L1210 cell lines. Compounds 2c and 2d exhibit inhibitory potency for topoisomerase-II comparable to that of etoposide. ${ }^{6,7}$ Compound $2 \mathrm{e}$ shows moderate binding affinity towards human neurokinin- $1\left(\mathrm{hNK}_{1}\right)$ receptors in the central nervous system. ${ }^{1}$

The NorA protein is a multidrug resistant efflux in the bacterium Staphylococcus aureus. This has resulted in resistance towards numerous structurally dissimilar antibiotics such as norfloxacin, ethidium bromide, berberine, etc. Isoindoloindolone $\mathbf{1}$ is used as a precursor in the synthesis of 2-aryl-5-nitroindoles as NorA efflux pump inhibitors. ${ }^{8,9}$ Isoindoloindolone $\mathbf{1}$ also exhibit charge-transfer fluorescence with high quantum yields in non polar solvents. ${ }^{10}$

\section{Synthetic Strategies}

Synthetic strategies of isoindoloindolones have been explored by research groups all over the world for decades (1979-2014) due to their diverse applications. Some of these efficient and remarkable achievements are discussed below.

\subsection{Palladium catalyzed coupling reactions}

Palladium acetate promoted intramolecular-dehydrogenative cyclisation of 1-benzoylindole is a short and simple method for the synthesis of isoindoloindolones (Scheme 1). ${ }^{11-18}$ It was first explored by Itahara in $1979^{11-14}$ and was further developed by many other research groups.

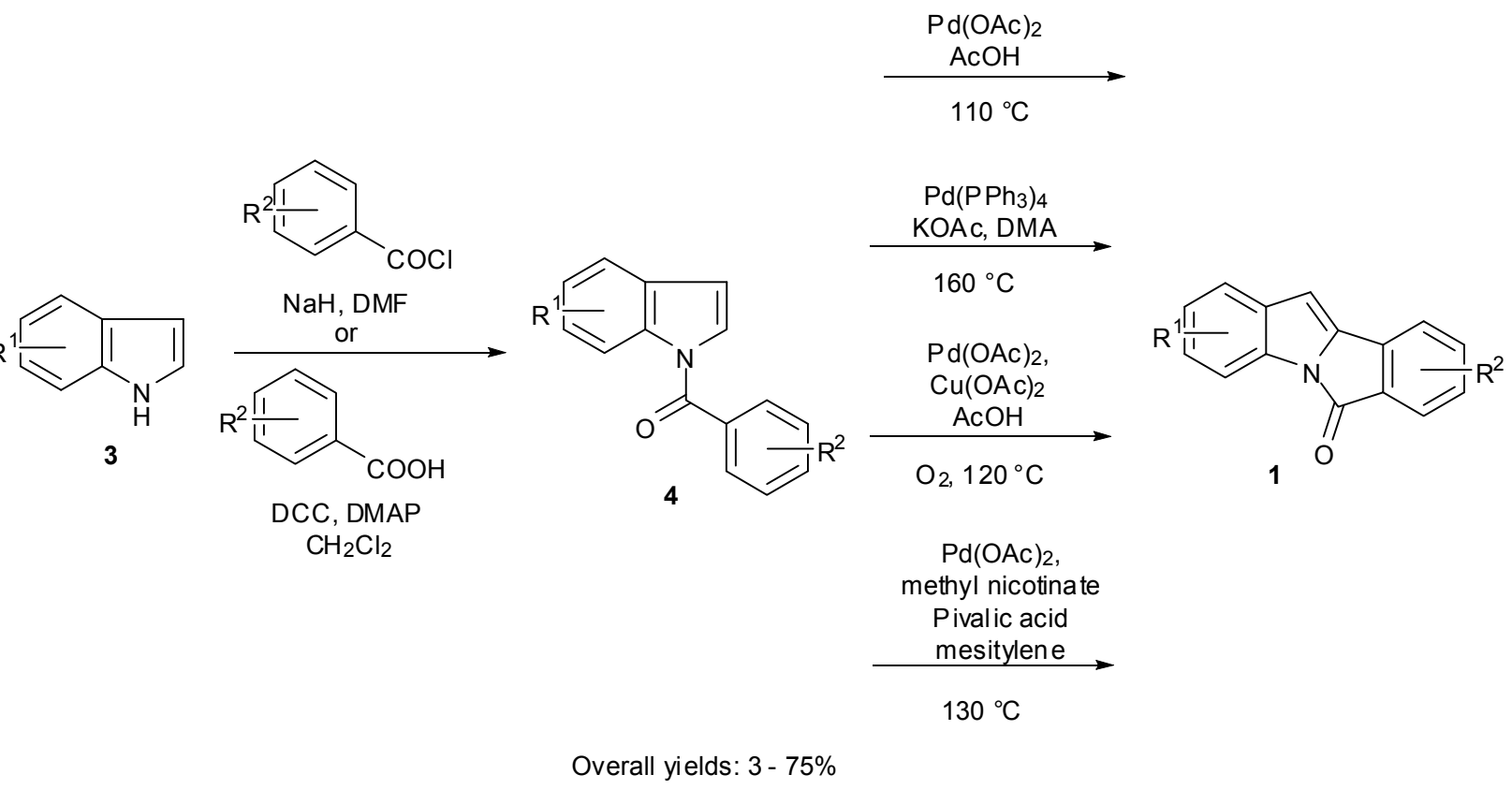

Scheme 1. Intramolecular-dehydrogenative cyclisation approach.

Bremner and his group ${ }^{8}$ prepared 1-benzoylindole 4 and reacted with palladium acetate in refluxing acetic acid to give isoindoloindolone 1. Dinnell et al. used $\mathrm{Pd}\left(\mathrm{PPh}_{3}\right)_{4}$ as catalyst and 
KOAc as a base in refluxing DMA for the synthesis of isoindoloindolones. ${ }^{1}$ DeBoef and coworkers used $\mathrm{Cu}(\mathrm{OAc})_{2}$ along with $\mathrm{Pd}(\mathrm{OAc})_{2}$ in refluxing acetic acid in $\mathrm{O}_{2}$ atmosphere for intramolecular aerobic oxidative coupling of 1-benzoylindoles to give isoindoloindolones. ${ }^{15}$ Electron rich tethered arenes gave better yields than unsubstituted arenes. Kandukuri and Oestreich used methyl nicotinate as ligand for $\mathrm{Pd}(\mathrm{OAc})_{2}$ in mesitylene and pivalic acid in $\mathrm{O}_{2}$ atmosphere for aerobic dehydrogenative double $\mathrm{C}-\mathrm{H}$ coupling in 1-benzoylindoles to give isoindoloindolones. ${ }^{16}$

Hibino and co-workers prepared isoindoloindolone by employing Suzuki-Miyaura reaction of $N$-Boc-indole-boronic acid 5 and methyl-o-iodobenzoate $\mathbf{6}$ to give $N$-Boc-indole esters 7 followed by deprotection to give prominent precursor $\mathbf{8}$ and finally base mediated cyclisation to isoindoloindolones (Scheme 2). ${ }^{19}$ The method was further modified to complete the total synthesis of indoloquinoline alkaloid isocryptolepine.

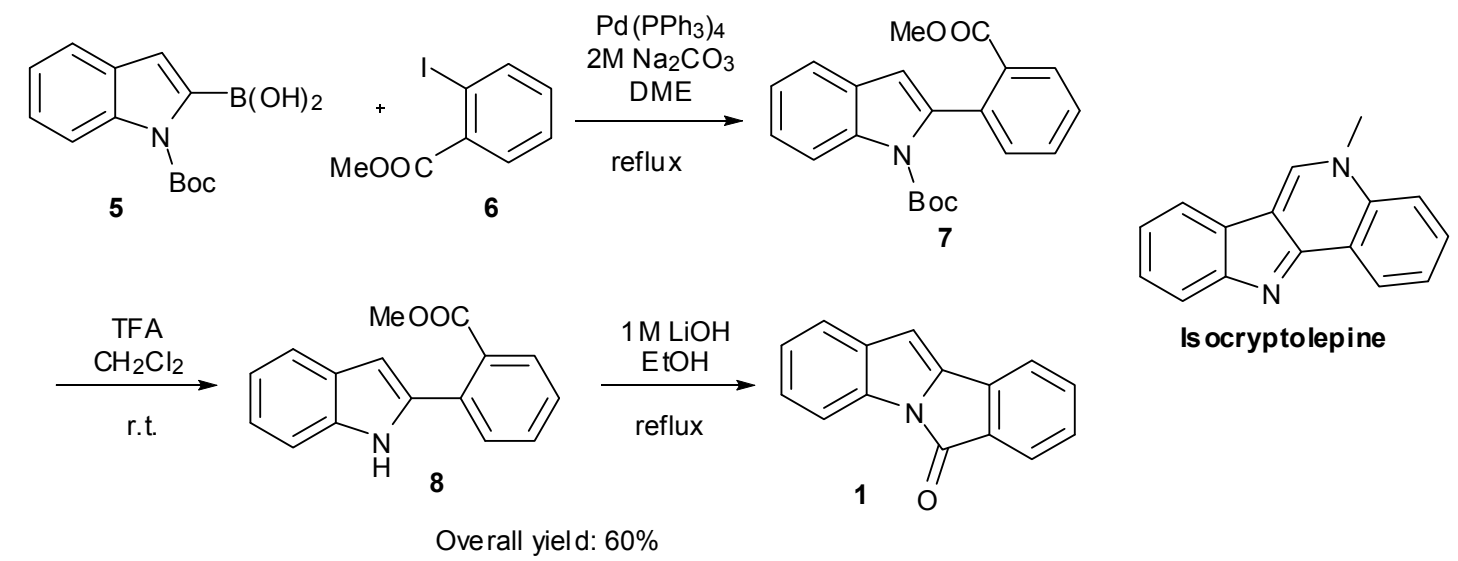

Scheme 2. Hibino's method.
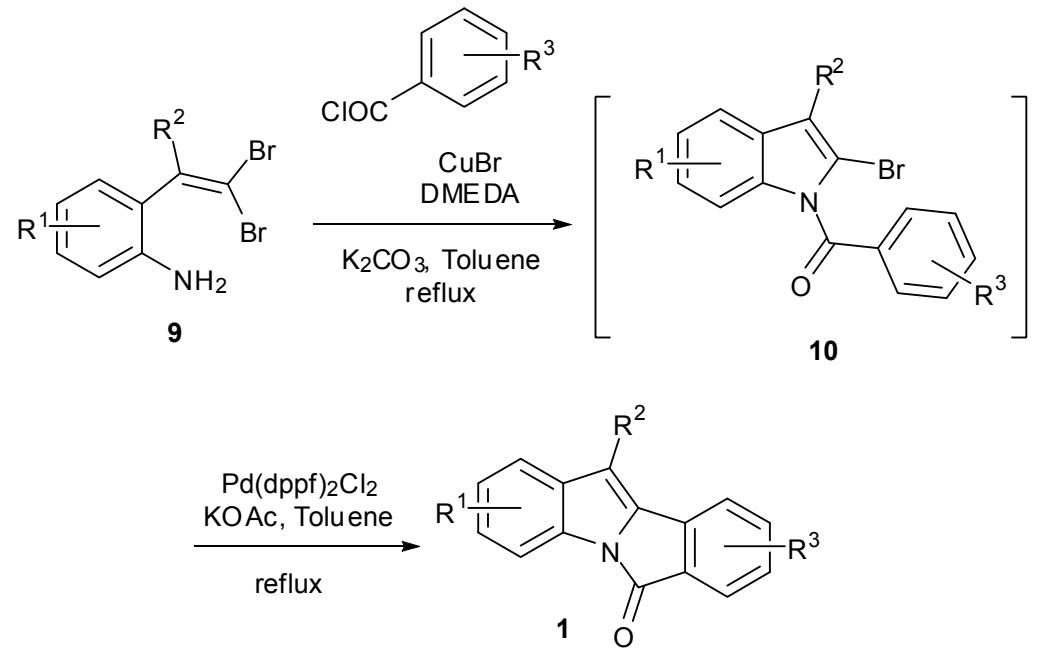

Scheme 3. Bao's method.

Bao's group ${ }^{20}$ reported a synthesis of isoindoloindolones through one-pot sequential Cu catalyzed 
C-N coupling and Pd catalyzed C-H activation reaction (Scheme 3). This two-step one-pot synthesis uses $o$-gem-dibromovinylanilines $\mathbf{9}$ as a starting material for benzoylation with benzoyl chloride and simultaneous intramolecular Buchwald-Hartwig $\mathrm{C}-\mathrm{N}$ coupling with $\mathrm{CuBr}$ catalyst to give $N$-benzoylated 2-bromoindole 10. Finally Pd catalyzed intramolecular Heck C-C coupling gave isoindoloindolones. Various derivatives with substituents on both aryl rings were prepared efficiently (Table 1) in moderate to good yields. The yields of 7-methyl and 10-chloro-11-methyl derivatives of 1 were somewhat low.

Table 1. Bao's method for isoindoloindolones

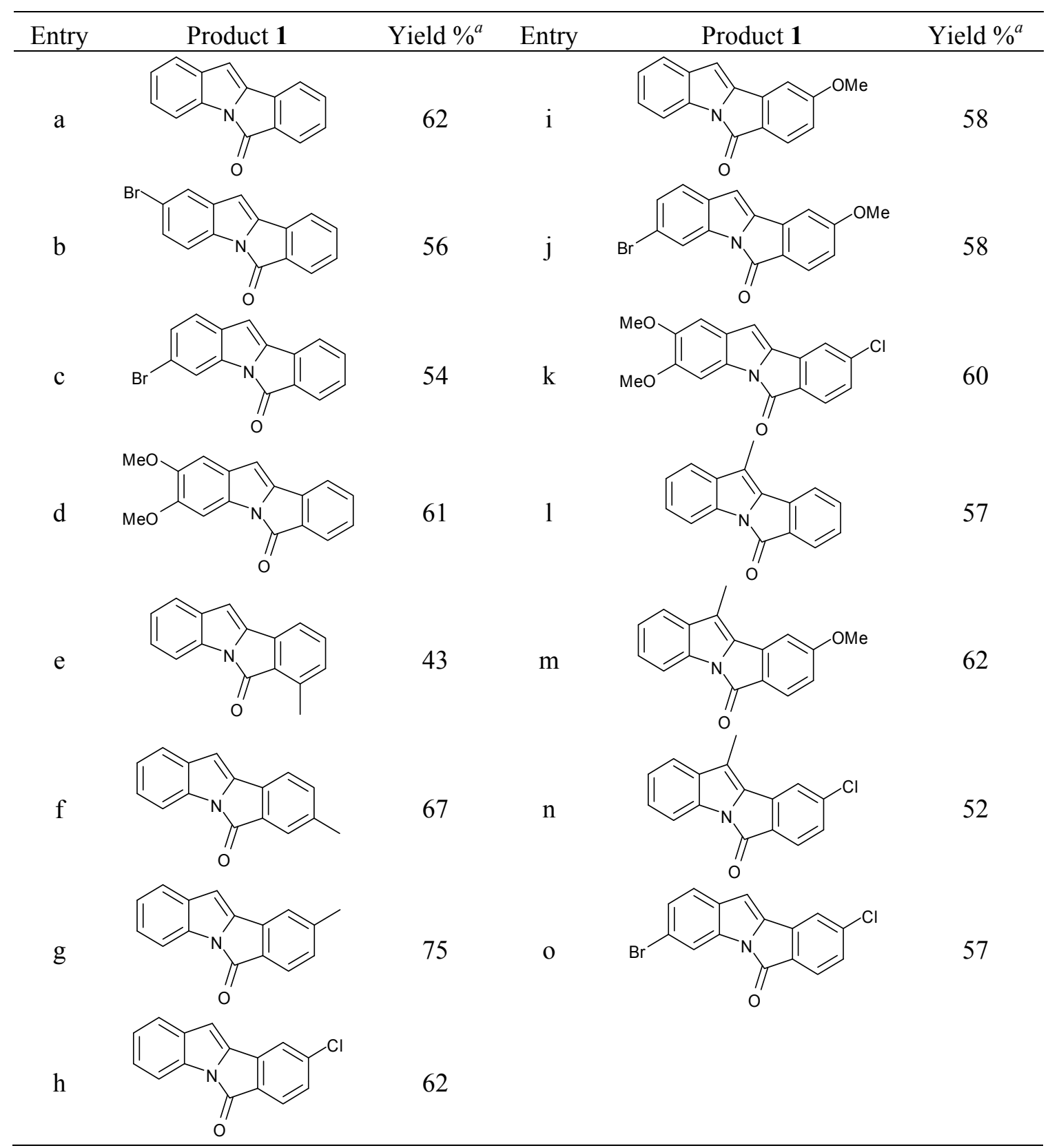

\footnotetext{
${ }^{a}$ Isolated yields.
} 
Cyclisation of dihalo- $N$-vinylbenzamide 13 to isoindoloindolone by tandem intramolecular Heck reaction is demonstrated by Dominguez's group taking advantage of difference in reactivity between two halo groups (Scheme 4). ${ }^{21}$ The required dihalo- $N$-vinylbenzamide 13 was obtained by condensation of $o$-bromoarylamine 11 with acetaldehyde followed by benzoylation with $o$-iodobenzoyl chloride 12. Chemoselective palladation with the iodo group of benzamide 13 to form methylene phthalimide intermediate via 5-exo-trig cyclisation followed by endo cyclisation furnished the isoindoloindolone. The overall yield of the sequence was $35 \%$.

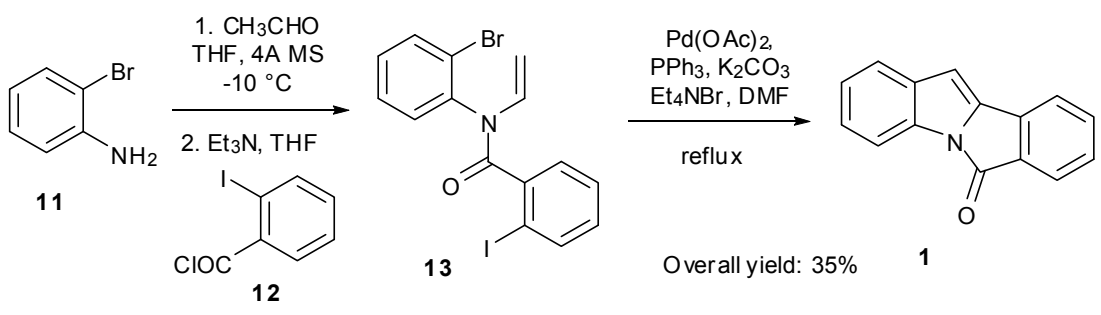

Scheme 4. Dominguez's method.

Estevez's laboratory reported a copper-mediated intramolecular cyclisation of methyl 2-(2aminophenylethynyl)benzoates 16 to isoindoloindolones (Scheme 5, Table 2). ${ }^{22}$ This precursor was prepared by double Sonogashira coupling reactions initially between trimethylsilylacetylene and methyl-o-iodobenzoate $\mathbf{6}$ then subsequently with $o$-iodoaniline 15. Though the chemistry involved in the synthesis is quite interesting, the low overall yields (6-38\%) discourage its application on a larger scale.<smiles>[R]c1ccc(I)c(C(=O)OC)c1</smiles>

6
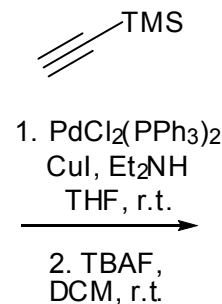

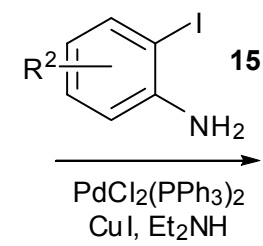

14

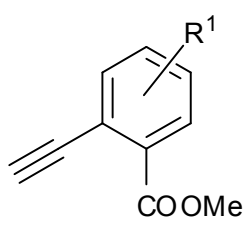

4 THF, r.t.<smiles>[R]c1ccc(C#Cc2cc[R1]cc2N)c(C(=O)O[Na])c1</smiles>

16

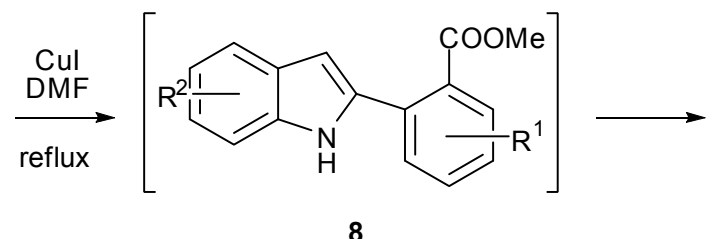

8

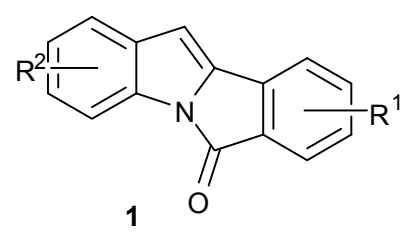

Scheme 5. Estevez's method. 
Table 2. Estevez's method for isoindoloindolones

Entry $\begin{gathered}\text { Overall } \\ \text { yield } \%^{a}\end{gathered}$ Entry

${ }^{a}$ Calculated over 3 steps.

Ponpandian and Muthusubramanian achieved isoindoloindolone synthesis using copper catalyzed domino $s p-s p^{2}$ decarboxylative cross coupling reaction of arylpropiolic acids $\mathbf{1 7}$ with $o$-iodotrifluoroacetanilide 18 and subsequent cyclisation (Scheme 6) in excellent yield. ${ }^{23}$ However, the scope of this method to prepare other derivatives was not studied.

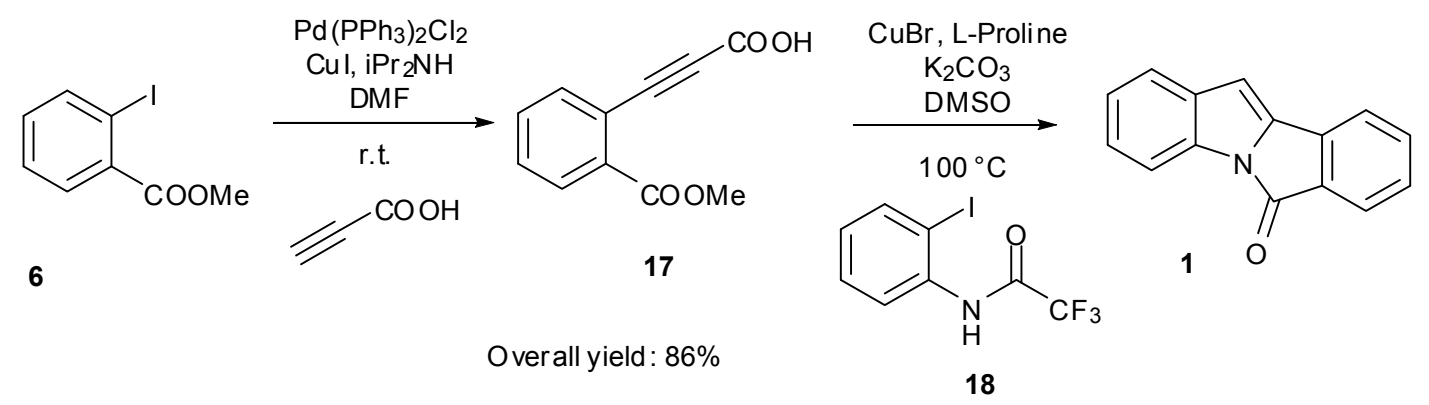

Scheme 6. Muthusubramanian's method.

Zhu and co-workers developed synthesis of isoindoloindolones with Pd-catalyzed intramolecular cyclization via tert-butyl isocyanide insertion on 2-(2-bromophenyl)- $1 H$-indoles 19 (Scheme 7, Table 3). ${ }^{24}$ This method efficiently demonstrates the utility of isocyanides in C-N or C-C bond construction with $\mathrm{N}$-tert-butyl intermediate 20. Using this method a library of twelve compounds was prepared in good to excellent yield.

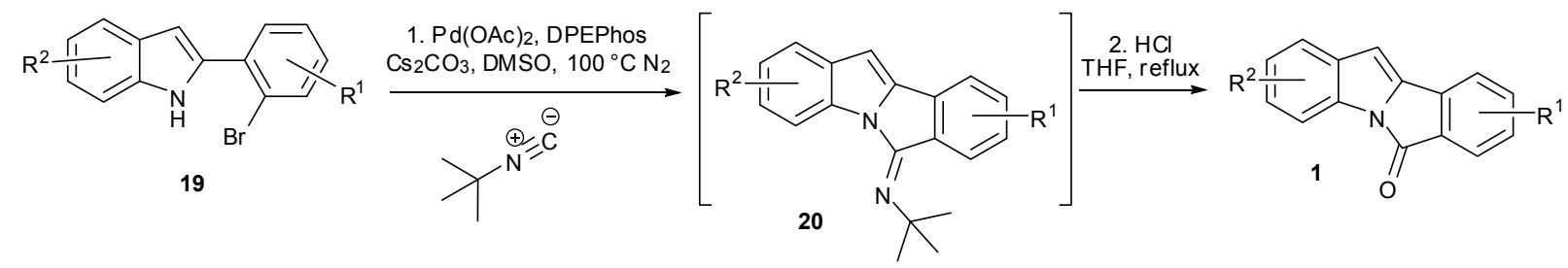

Scheme 7. Zhu's method. 
Table 3. Zhu's method for isoindoloindolones

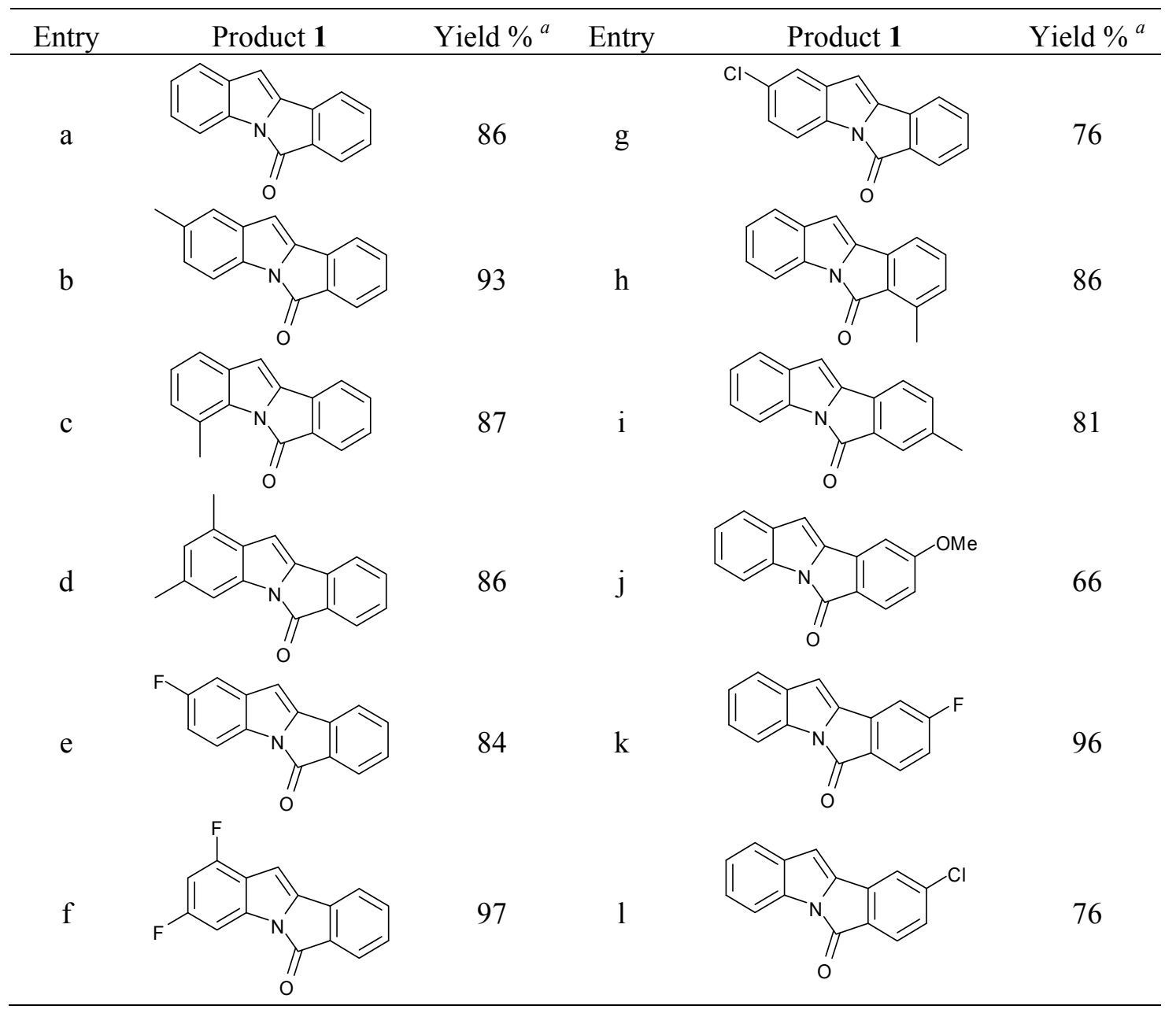

${ }^{a}$ Isolated yields.

\subsection{Wittig reactions}

Boutin and co-workers have developed a sequence involving Wittig olefination of $o$ nitrobenzaldehyde $\mathbf{2 1}$ with in situ phosphorane formed from the phosphonium salt $\mathbf{2 2}$ to give nitroarene 23. ${ }^{5}$ The nitro group was reduced by catalytic hydrogenation in the presence of Raney $\mathrm{Ni}$ followed by base hydrolysis of the amino-lactone 24 to give the indole acid 25 (Scheme 8). The acid was then converted into isoindoloindolones by refluxing in toluene in presence of $p$ TSA. Six isoindoloindolone derivatives with substituents on both the rings were prepared using this four-step protocol in overall yields of $32-58 \%$ (Table 4). 


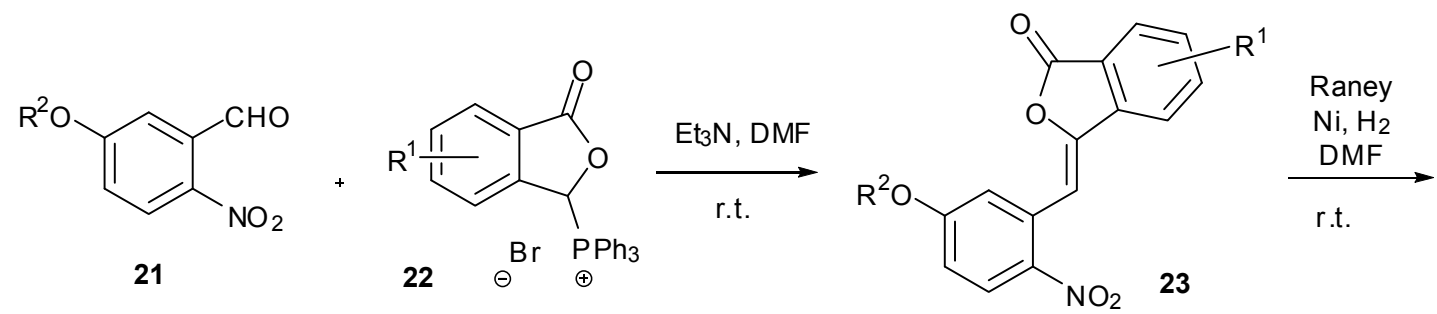

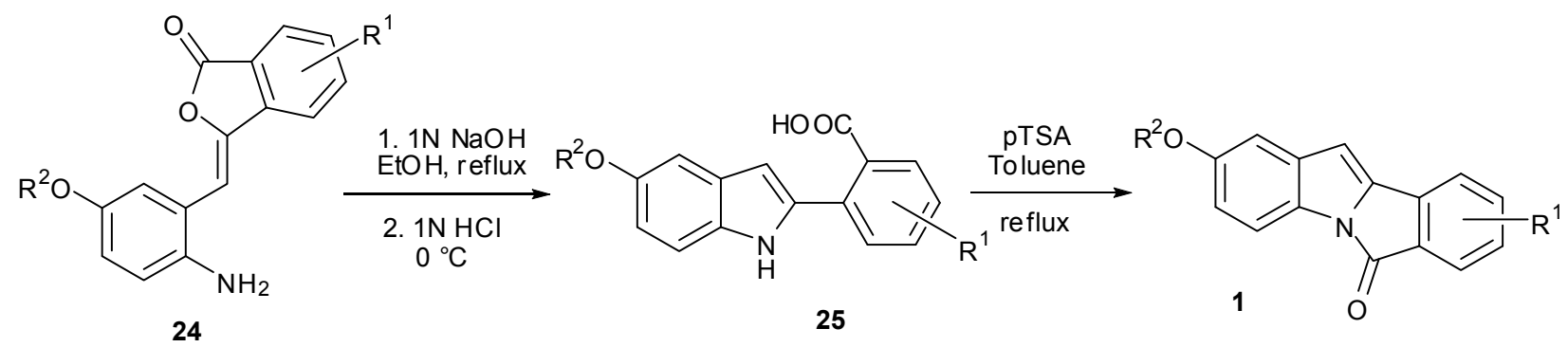

Scheme 8. Boutin's method.

Table 4. Boutin's method for isoindoloindolones

Entry

${ }^{a}$ Calculated over 4 steps

Our group has developed a two-step route to $6 H$-Isoindolo[2,1-a]indol-6-ones starting from $o$-nitrobenzaldehydes $\mathbf{2 6} .^{25}$ The methodology involves Wittig reaction followed by tandem reductive cyclization-lactamization (Scheme 9). 


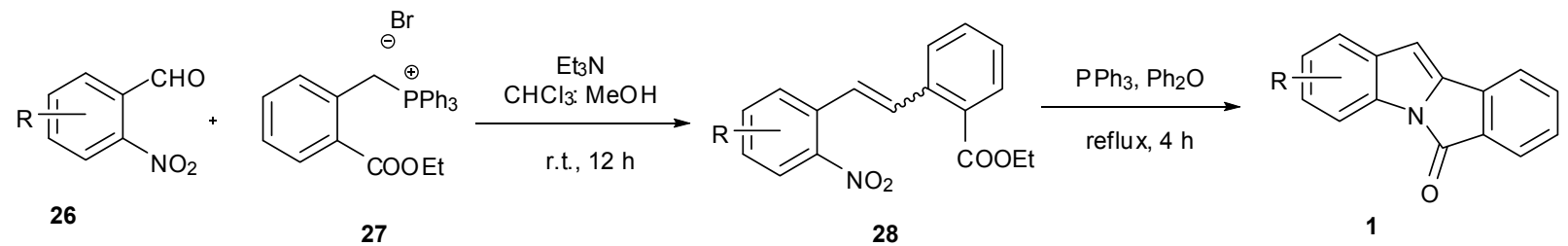

Scheme 9. Tilve's method.

Table 5. Tilve's method for isoindoloindolones

Entry $\begin{gathered}\text { Overall } \\ \text { yield } \%^{a}\end{gathered}$ Entry

${ }^{a}$ Calculated over 2 steps.

Various substituted $o$-nitrobenzaldehydes were subjected to Wittig reaction with the phosphorane formed from the benzylic phosphorus salt 27 to obtain the corresponding substituted ethyl 2-(2-nitrostyryl)benzoates 28. These were then subjected to tandem reductive cyclisation - lactamization using $\mathrm{PPh}_{3}$ in refluxing diphenyl ether. The corresponding isoindoloindolones were obtained in good overall yields. (Table 5) The flexibility of this method was demonstrated by synthesizing a series of isoindoloindolones with electron-donating groups like methoxy, dimethoxy, trimethoxy, and methylenedioxy, as well as electron-withdrawing groups like chloro.

Intramolecular Wittig reaction is employed as a key step by Monneret and his group ${ }^{6-7}$ to synthesize isoindoloindolones (Scheme 10, Table 6). The Wittig salt 32 was prepared by benzylic bromination of $N$-(o-tolyl)-phthalimides 31 followed by reaction with $\mathrm{PPh}_{3}$. The overall yield of the four compounds ranges from $28-55 \%$. 


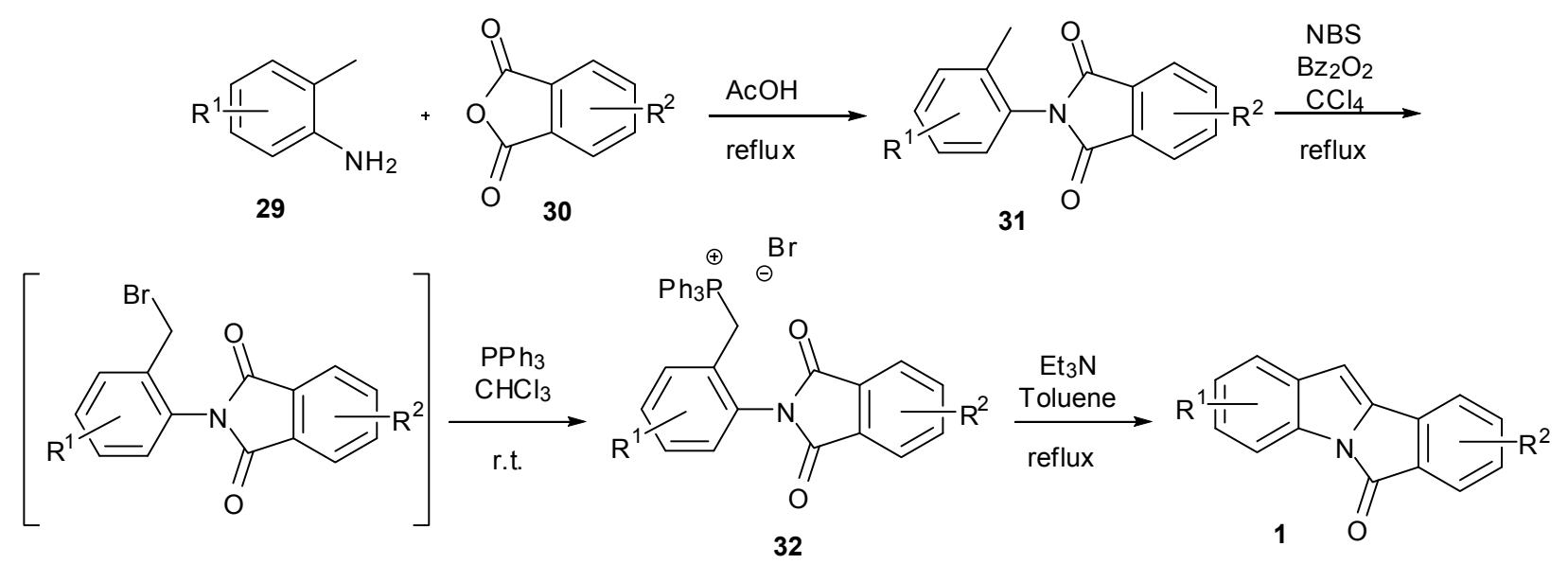

Scheme 10. Monneret's method.

Table 6. Monneret's method for isoindoloindolones

Entry

${ }^{a}$ Calculated over 3 steps.

\subsection{Miscellaneous approaches}

Griffiths and his group ${ }^{26}$ developed a novel route to isoindoloindolones using $o-(N-$ phthaloyl)benzoic acids 34 (Scheme 11, Table 7). The process involves formation of acid chlorides followed by reaction with triethyl phosphite to give tetracyclic- $\beta$-keto phosphonates $\mathbf{3 5}$ via a carbon-carbon bond forming reaction involving phosphonate anion. This ketoamide phosphonate 35 on reduction with $\mathrm{NaBH}_{4}$ furnished the required isoindoloindolones in 31-44 \% overall yields. 


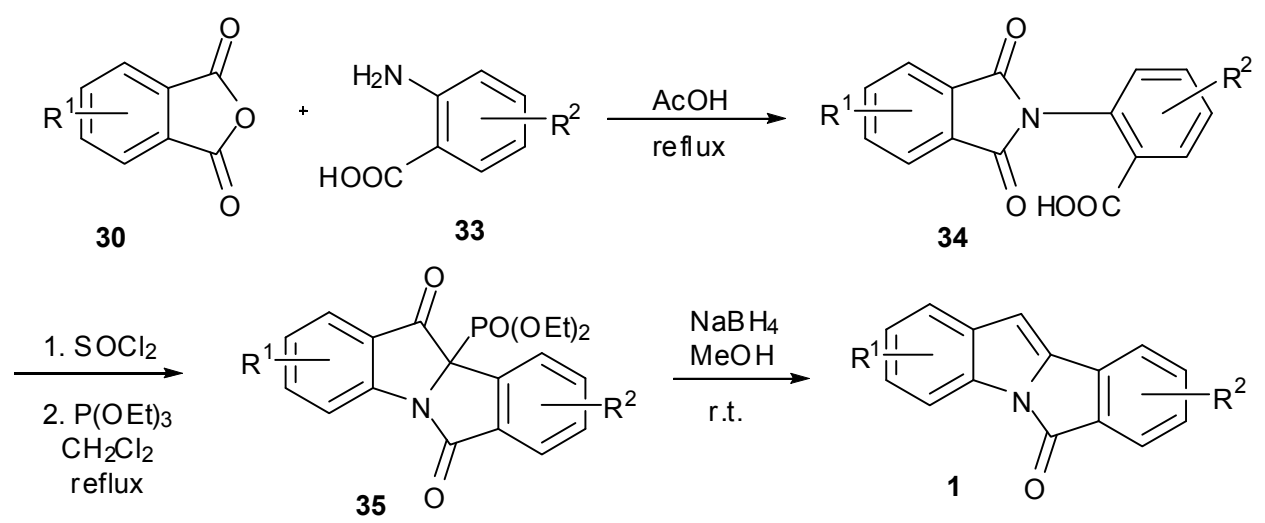

Scheme 11. Griffiths's method.

Table 7. Griffiths's method for isoindoloindolones

Entry $\begin{gathered}\text { Overall } \\ \text { yield } \%^{a}\end{gathered}$ Entry

${ }^{a}$ Calculated over 3 steps.

Flash vacuum pyrolysis of methyl-2-(indol-1-yl)-benzoate 37 to isoindoindolone was developed by McNab et al..$^{27,28}$ (Scheme 12). Here high temperature cascade reaction involving sigmatropic shift-elimination-cyclisation provided isoindoloindolone. Methyl 2-(indol-1-yl)benzoate 37 was prepared by $\mathrm{C}-\mathrm{N}$ coupling of indole and $o$-iodobenzoic acid followed by esterification.
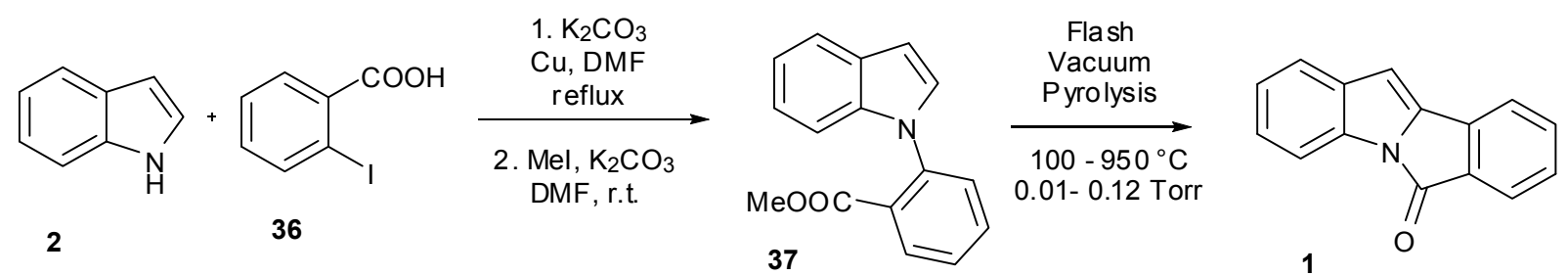

Overall yield: $26 \%$

Scheme 12. McNab's method. 
Kanaoka's group ${ }^{29-31}$ has developed a photochemical isoindoloindolone synthesis. UV irradiation of $N$-(o-tolyl)tetrachlorophthalimide 38 resulted in photocyclisation to give the tetracyclic alcohol 39. Further dehydration in presence of acid gave tetrachloroisoindoloindolone 40 (Scheme 13).

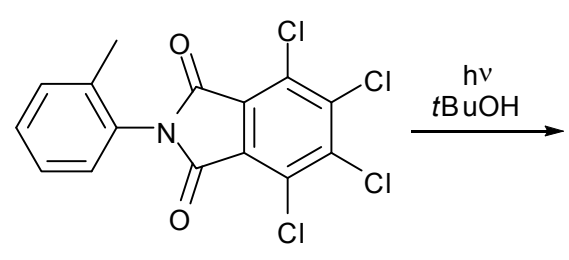

38

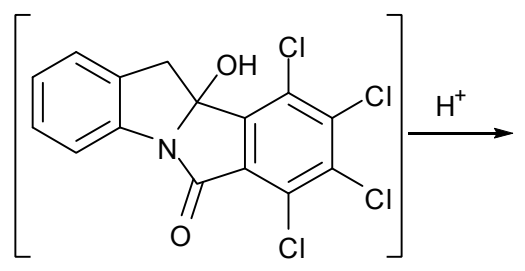

Overall yield: $22 \%$<smiles>O=C1c2c(Cl)c(Cl)c(Cl)c(Cl)c2-c2cc3ccccc3n21</smiles>

40

Scheme 13. Kanaoka's method.

A metal free synthesis of isoindoloindolone was reported by Wang's group using dibenzocyclohepten-5-one $\mathbf{4 1}$ as starting material (Scheme 14). ${ }^{32}$ This method involves Beckmann rearrangement of the oxime $\mathbf{4 2}$ to the lactam 43 using TFA, followed by bromination and intramolecular cyclisation of dibromodihydrodibenzoazocin-6-one $\mathbf{4 4}$ to yield isoindoloindolone.<smiles>O=c1c2ccccc2ccc2ccccc12</smiles>

41<smiles>N=c1c2ccccc2ccc2ccccc12</smiles>

42<smiles>O=C1Nc2ccccc2/C=C\c2ccc(C(F)(F)F)cc21</smiles>

43<smiles>CCN1C(=O)c2ccccc2C(Br)C(Br)c2ccccc2NC(=O)c2ccccc21</smiles>

Scheme 14. Wang's method.

\section{Conclusions}

The synthesis of isoindoloindolones has been extensively studied on account of their diverse biological applications. The methods use different approaches for constructing the indole or isoindole ring. Palladium-catalyzed cyclisation to the indole C-2 is widely used in assembling the isoindole ring. The Wittig reaction was also explored in a few approaches for assembling the 
indole ring. Clean and high yielding general strategies are required for making newer analogues for biological testing.

\section{Acknowledgements}

The authors acknowledge financial assistance from the Council of Scientific and Industrial Research (CSIR), the University Grants Commission (UGC) and the Department of Science and Technology (DST), New Delhi.

\section{References}

1. Dinnell, K.; Chicchi, G. G.; Dhar, M. J.; Elliott, J. M.; Hollingworth, G. J.; Kurtz, M. M.; Ridgill, M. P.; Rycroft, W.; Tsao, K. L.; Williams, A. R.; Swain, C. J. Bioorg. Med. Chem. Lett. 2001, 11, 1237. http://dx.doi.org/10.1016/S0960-894X(01)00183-4

2. Carruthers, W.; Evans, N. J. Chem. Soc. Perkin Trans. 1 1974, 1523. http://dx.doi.org/10.1039/p19740001523

3. Hooper, M.; Imam, S. H. J. Chem. Soc. Perkin Trans. 1 1985, 1583. http://dx.doi.org/10.1039/p19850001583

4. Liegault, B.; Lee, D.; Huestis, M. P.; Stuart, D. R.; Fagnou, K. J. Org. Chem. 2008, 73, 5022. http://dx.doi.org/10.1021/jo800596m

5. Boussard, M. F.; Truche, S.; Rousseau, A.; Briss, S.; Descamps, S.; Droual, M.; Wierzbicki, M.; Ferry, G.; Audinot, V.; Delagrange, P.; Boutin, J. Eur. J. Med. Chem. 2006, 41, 306. http://dx.doi.org/10.1016/j.ejmech.2005.12.002

6. Guillaumel, J.; Leonce, S.; Pierre, A.; Renard, P.; Pfeiffer, B.; Arimondo, P. B.; Monneret, C. Eur. J. Med. Chem. 2006, 41, 379.

http://dx.doi.org/10.1016/j.ejmech.2005.10.008

7. Guillaumel, J.; Leonce, S.; Pierre, A.; Renard, P.; Pfeiffer, B.; Peruchon, L.; Arimondo, P. B.; Monneret, C. Oncol. Res. 2003, 13, 537.

8. Ambrus, J. I.; Kelso, M. J.; Bremner, J. B.; Ball, A. R.; Casadei, G.; Lewis, K. Bioorg. Med. Chem. Lett. 2008, 18, 4294.

http://dx.doi.org/10.1016/j.bmcl.2008.06.093

9. Samosorn, S.; Bremner, J. B.; Ball, A. R.; Lewis, K. Bioorg. Med. Chem. 2006, 14, 857. http://dx.doi.org/10.1016/j.bmc.2005.09.019

10. Disanayaka, B. W.; Weedon, A. C. Can. J. Chem. 1987, 65, 245. http://dx.doi.org/10.1139/v87-040

11. Itahara, T. Synthesis 1979, 151. http://dx.doi.org/10.1055/s-1979-28600

12. Itahara, T. Bull. Chem. Soc. Jpn. 1981, 305. http://dx.doi.org/10.1246/bcsj.54.305

13. Itahara, T. Chem. Lett. 1982, 1151. 
http://dx.doi.org/10.1246/c1.1982.1151

14. Itahara, T. Heterocycles 1986, 24, 2557. http://dx.doi.org/10.3987/R-1986-09-2557

15. Dwight, T. A.; Rue, N. R.; Charyk, D.; Josselyn, R.; DeBoef, B. Org. Lett. 2007, 9, 3137. http://dx.doi.org/10.1021/o1071308z

16. Kandukuri, S. R.; Oestreich, M. J. Org. Chem. 2012, 77, 8750. http://dx.doi.org/10.1021/jo301088f

17. Kozikowski, A. P.; Ma, D. Tetrahedron Lett. 1991, 32, 3317. http://dx.doi.org/10.1016/S0040-4039(00)92695-9

18. Grigg, R.; Sridharan, V.; Stevenson, P.; Sukirthalingam, S.; Worakun, T. Tetrahedron 1990, 46, 4003.

http://dx.doi.org/10.1016/S0040-4020(01)90535-6

19. Hayashi, K.; Choshi, T.; Chikaraishi, K.; Oda, A.; Yoshinaga, R.; Hatae, N.; Ishikura, M.; Hibino, S. Tetrahedron 2012, 68, 4274. http://dx.doi.org/10.1016/j.tet.2012.03.055

20. He, H.; Dong, S.; Chen, Y.; Yang, Y.; Le, Y.; Bao, W. Tetrahedron 2012, 68, 3112. http://dx.doi.org/10.1016/j.tet.2012.01.087

21. Garcia, A.; Rodriguez, D.; Castedo, L.; Saa, C.; Dominguez, D. Tetrahedron Lett. 2001, 42, 1903. http://dx.doi.org/10.1016/S0040-4039(01)00077-6

22. Reboredo, F. J.; Treus, M.; Estevez, J. C.; Castedo, L. ; Estevez, R. J. Synlett 2003, 1603.

23. Ponpandian, T.; Muthusubramanian, S. Tetrahedron Lett. 2012, 53, 4248. http://dx.doi.org/10.1016/j.tetlet.2012.06.023

24. Tang, T.; Jiang, X.; Wang, J. M.; Sun, Y. X.; Zhu, Y. M. Tetrahedron 2014, 70, 2999. http://dx.doi.org/10.1016/j.tetlet.2012.06.023

25. Kadam, H. K.; Tilve, S. G. Eur. J. Org. Chem. 2013, 4280. http://dx.doi.org/10.1002/ejoc.201300047

26. Duncanson, P.; Cheong, Y.; Motevalli M.; Griffiths, D. V. Org. Biomol. Chem. 2012, 10, 4266. http://dx.doi.org/10.1039/c2ob25314c

27. Crawford, L. A.; Clemence, N. C.; McNab, H.; Tyas, R. G. Org. Biomol. Chem. 2008, 6, 2334. http://dx.doi.org/10.1039/b802273a

28. McNab, H.; Parsons, S.; Stevenson, E. J. Chem. Soc. Perkin Trans. 1 1999, 2047. http://dx.doi.org/10.1039/a904885e

29. Kanaoka, Y.; Koyama, K. Tetrahedron Lett. 1972, 44, 4517. http://dx.doi.org/10.1016/S0040-4039(01)94356-4

30. Kanaoka, Y.; Nagasawa, C. Heterocycles 1975, 3, 553. http://dx.doi.org/10.3987/R-1975-07-0553

31. Terashima, M.; Koyama, K. and Kanaoka, Y. Chem. Pharm. Bull. 1978, 26, 630. http://dx.doi.org/10.1248/cpb.26.630

32. Dai, C.; A. B. Draganov, A. B.; Wang, B. Heterocycl. Commun. 2010, 16, 245. 


\section{Authors' Biographies}

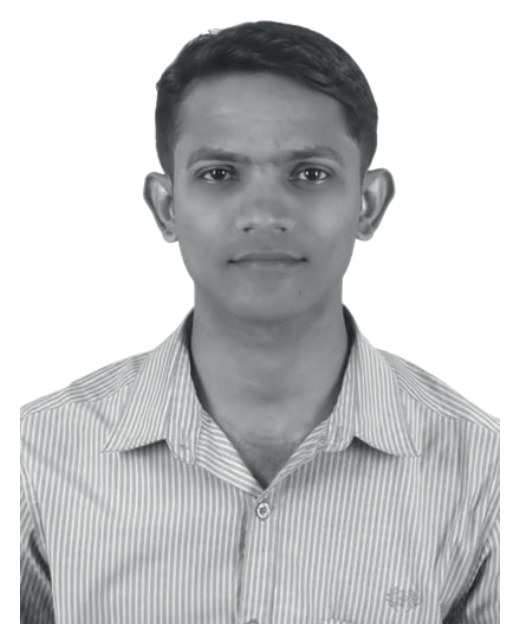

Dr. Hari K. Kadam (born in Goa, India) completed his M.Sc. (Organic Chemistry) with Gold Medal in 2009 from Goa University and simultaneously cleared the CSIR-UGC NET JRF exam. He received his Ph.D. degree in 2015 from Goa University under the supervision of Prof. S. G. Tilve. Presently, he is employed in St. Xavier's College, Goa as Assistant Professor in Chemistry. His current research interests include the synthesis of bioactive heterocyclic compounds and cross coupling reactions.

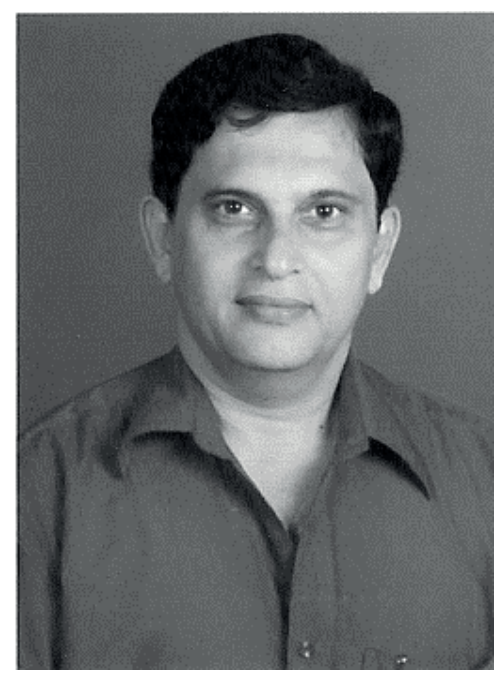

Prof. Santosh G. Tilve is a Professor of Organic Chemistry at the Dept. of Chemistry, Goa University. He received his Ph.D. degree in 1989 from Pune University under the supervision of Prof. R. S. Mali. After working in the chemical industry for six months, he started his academic career as a Lecturer at Goa University. He was promoted to Associate Professor in 1999 and to full Professor in 2007. He also worked as a Visiting Fellow with Prof. I. Blair at the Pennsylvania University, USA in 2000-2002. His current research interests include asymmetric synthesis, heterocycles, green chemistry, domino reactions and nano composites as catalyst. 